Електронне наукове фахове видання "Ефективна економіка" включено до переліку наукових фахових видань України з питань економіки

(Категорія «Б», Наказ Міністерства освіти і науки України від 11.07.2019 № 975) www. economy.nayka.com.ua |№ 3, 2021 | 25.03.2021 p.

DOI: $\underline{10.32702 / 2307-2105-2021.3 .70}$

UDC 65.016:622.012

Yu Papizh

PhD in Economics, Associate Professor,

Associate Professor of the Department of Management, Dnipro University of Technology

ORCID ID: 0000-0001-6460-7862

A. Kosolapov

PhD in Technical Sciences, Associate Professor,

Associate Professor of the Department of Geodesy, Dnipro University of Technology

ORCID ID: 0000-0001-8931-0352

V. Yudenko

Asssitant of the Department of Management, Dnipro University of Technology

ORCID ID: 0000-0001-7118-9128

\title{
MANAGEMENT OF THE MINING ENTERPRISES IN A SUSTAINABLE WAY
}

\author{
Ю. С. Папіж, \\ к. е. н., дочент, дочент кафедри менеджменту, \\ Національний технічний університет «Дніпровська політехніка», \\ А. Ф. Косолапов, \\ к. т. н.., доиент, дочент кафедри геодезії, \\ Начіональний технічний університет «Дніпровська політехніка», \\ В. В. Юденко, \\ асистент кафедри менеджменту, \\ Начіональний технічний університет «Дніпровська політехніка»,

\section{УПРАВЛІННЯ ГІРНИЧОДОБУВНИМИ ПІДПРИЕМСТВАМИ НА ЗАСАДАХ СТІЙкОСТІ}

Sustainable development of a mining company is affected significantly by principals of external economic environment that is local, national and global economies. The problem of choosing a model of sustainable development of a mining enterprise is determined, which makes it possible to predict the trajectory of its development in the short and long term, the choice of optimal solutions. The actual balance between economic, ecological and social sectors of mining company development is influenced by many factors intrinsic to developing countries. The following impact factors can be outlined among others. A vertical between lowest company level and highest national economy level of sustainable development is not introduced yet. Rapid changes of politics that are as unexpected as close to uncertainty usually come with changes of current pattern of stakeholders' diversity that has negative impact on strategic planning. As a consequence sustainable development framework need to be improved for the mining company purposes. In turn achieving its sustainability requires a new approach to strategic planning, monitoring and reviewing activities of the mining company as sustainable development applies for sustainable management. Therefore 
running mining company in a sustainable way means that interests of all economic agents are met optimally subject to constraints on sustainable development principals, lifecycle of the company is as long as possible and its profitability is resilient to unfortunate costs. It is proposed to manage the mining enterprise in order to ensure its sustainable development on the basis of the principle of sustainable development based on the value of the object. The main purpose of this method is to monitor production costs in order to reduce them and redistribute overhead costs. In this case, the object of cost accounting (function, process, cost generation center) differs from the object of costing, which represents products and services. Thus, the integration of these provisions in order to adapt to the harmonious development of the mining company can help resolve the conflict between the principles of sustainable development and the rules of a market economy.

На сталий розвиток гірничодобувного підприємства суттєво впливають принципи зовнішнього економічного середовища, щзо визначаються місцевою, національною та світовою економіками. Визначено проблему вибору моделі сталого розвитку гірничодобувного підприємства, щзо дає змогу прогнозувати траєкторію його розвитку в короткостроковій та довгостроковій перспективах, здійснювати вибір оптимальних рімень. На фактичний баланс між економічним, екологічним та соціальним секторами розвитку гірничодобувного підприємства впливає багато факторів, властивих країнам, щуо розвиваються. Серед інших можна виділити наступні фактори впливу. Вертикаль між найнижчим рівнем розвитку компаній та найвищим рівнем стійкого розвитку в наиіональній економіці ще не встановлена. Швидкі зміни у політиці, несподіваность яких можна визначити близько до категрії невизначеності, зазвичай відбуваються зі змінами нинімньої моделі кола стейкхолдерів, щзо негативно впливає на стратегічне планування. Як наслідок, положення концепції сталого розвитку повинні бути вдосконалені для досягнення еефктивності діяльності гірничодобувних підприємств. У свою чергу досягнення иієї стійкості вимагає нового підходу до стратегічного планування, моніторингу та перегляду діяльності гірничодобувних підприємств, оскільки сталий розвиток застосовується до сталого управління. Отже, управління гірничодобувним підприємством на засадах стійкості означає, щцо інтереси всіх економічних суб'єктів оптимально задовольняються з урахуванням обмежень принщипів сталого розвитку, життєвий цикл підприємства $\epsilon$ якомога довшим, а його прибутковість стійкою до несподіваних витрат. Запропоновано здійснювати управління гірничодобувним підприємством на засадах стійкості на основі принципу сталого розвитку, заснованого на вартості об'єкта. Основною метою иього методу є моніторинг виробничих витрат з метою їх зменшення та перерозподілу накладних витрат. При изьому об'єкт обліку витрат (функиія, процес, иентр формування витрат) відрізняється від об'єкта калькулящії, який представляє продукиію та послуги. Таким чином, інтеграція ичих положень з метою адаптаџії до гармонійного розвитку гірничодобувного підприсмства може допомогти вирішити конфлікт між принципами сталого розвитку та правилами ринкової економіки.

Key words: mining enterprises; management; sustainability; development; market economy.

Ключові слова: гірничодобувні підприємства; управління; стійкість; розвиток; ринкова економіка.

Introduction. Exploring the core essence of sustainable development namely its principals and concepts, analyzing relationship of sustainable development and other economic theories and studying current ideas of how to make mining companies to growth sustainably provide some insights into contradictory connection of sustainable development itself and mining company activities within the market economy. As we see it these contradictory challenges remaining untaken up prevent mining companies from adhering to balanced economic, environmental and social interests in practice and disallow to put economic, social and ecologic sectors of internal and external environment together around the mining company providing its integration into local and national economies.

Analysis of recent research and publications. Existing models of sustainable development, which under certain modifications can be applied to mining enterprises, can be divided into three classes: mathematical, graphical 
and combined models. Among them are the following: the model of global sustainable development of Phillips J. [5], the model of sustainable development of the enterprise Krainka D., Glavik P. [2], the model of sustainable development of cities Marquez B., Espinoza-Fernandez I. [2], model of sustainable development of underdeveloped communities Angulo F., Olivara J. [3], cognitive model of sustainable innovative development of enterprise Bogatikova V.M [7], cybernetic model of functioning of the industrial enterprise Forrester D. [17], simulation model of sustainable development of small and medium industrial enterprise Maligina S.N., Abalimova D.M. [11], cognitive map of sustainable development of the city Petrikova E.M. [14]. Thus, the analysis of sustainable development models presented in the scientific literature allows us to conclude that representatives of European scientific schools pay more attention to building graphical models, while scientists from other countries focus on mathematical modeling of socioecological and economic processes.

The arm of the article is to determine the possibility of managing mining enterprises in order to ensure their sustainable development on the basis of the principles of sustainable development and the rules of a market economy.

Results. The first challenge could be described as fundamental contradiction between postulates of the market economy according to which mining companies perform and managers' estimation of a level of importance and significance that social and environmental projects are of. As a consequence it mirrors their attitude to such projects which in such case do not occupy priority positions among company goals. Saying reverse sustainable development process is considered by managers and owners of assets to be of high cost and low benefit.

At the same time a mining company is committed to the market economy rules and recognizes benefit as the only one driver for its activities. Unfortunately usual results and outcomes of ecologic and social projects benefit society as they are services provided in education, health, culture and rest sectors without direct financial profit for a company.

Not having a clear measurable indicator to evaluate positive effect of their impact on the company image or market value makes sustainable development projects to be evaluated abstractly and subjectively. Rising in market value of sustainably developed company and its climbing up to the top of ranking among different companies are worth moving towards sustainability if the company is actually a corporation, being sold and meets eligible financial criteria to be finally ranked. Otherwise social and environmental projects require to be financed at the expense of the company with reducing the profit gained. By extension, alternative cost of such projects accounted as virtual effect that would be achieved due to financing other economic business may exceed ecologic and social effect as assessed by experts and seen after sustainable development measures. All this pushes risks that the company will refuse to take social and ecologic projects up especially under conditions of new top management board or new owners being introduced or particularly without any government subsidies being provided.

Thence the conceptual platform for sustainable development of mining company is required to integrate the process of sustainable development itself into market economy model to ensure that the company benefits from being committed to sustainability principals and that such benefit is clearly measured in money equivalent. Globally there is a good example of it concerning artificially made world market for quotas on $\mathrm{CO}_{2}$ emissions according to Kyoto Protocol where a company is able to sell unused quotas to other demanders secured after implementing innovative green technologies. In such the case green technologies become an investment project with certain level of profit.

It was found that a mining company by its nature violates the principles of sustainable development not only during active operation stage of its life cycle, but also after its liquidation as an economic entity.

Then a dilemma arises. It is proposed to think it of as a dilemma of transitioned stability roll in the development of the mining company (Sustainability Roll in Transitive Mining) (Fig. 1). 


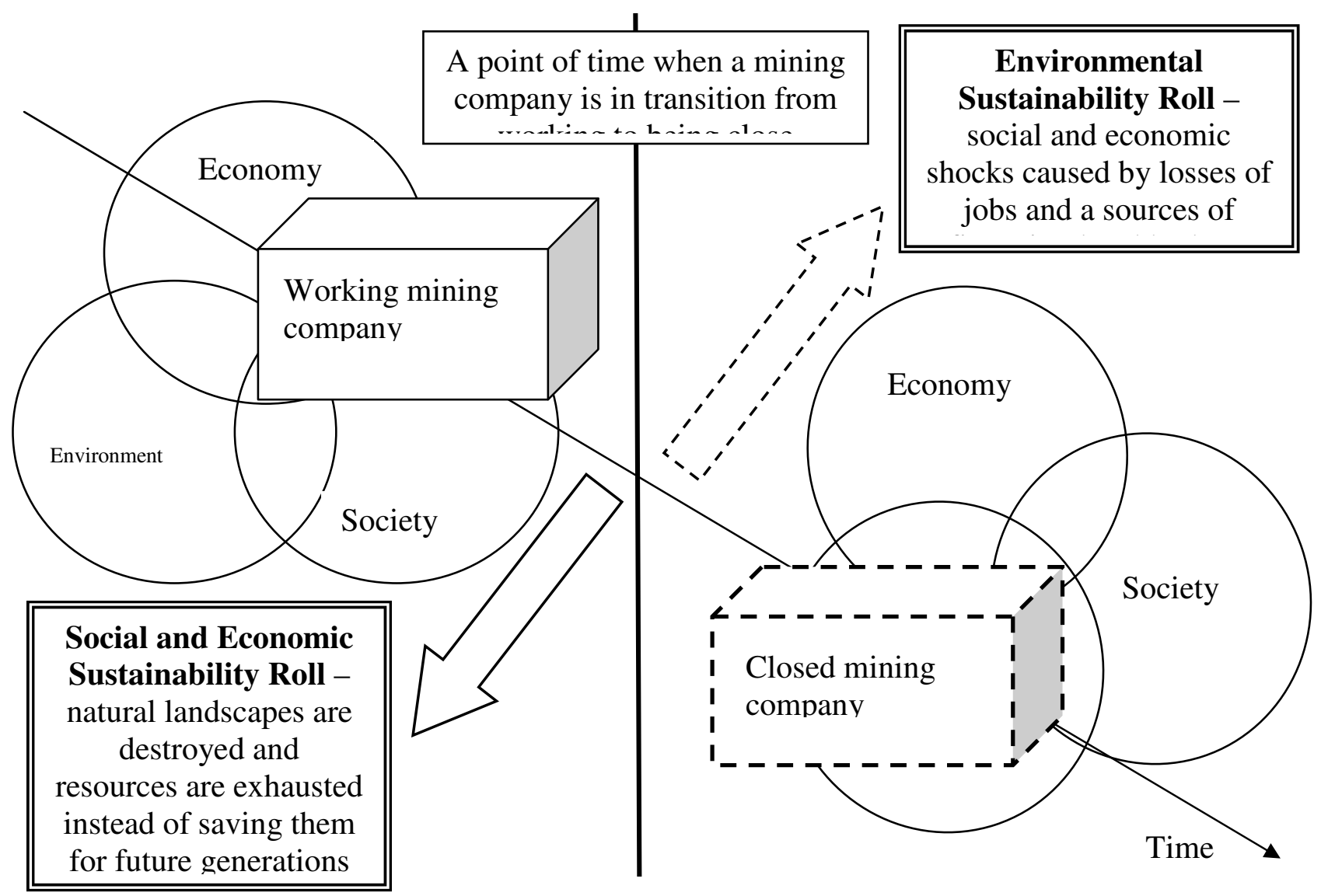

Fig. 1. Sustainability Roll in Mining Transition

The economic essence of sustainability roll observed during the development of the mining enterprise can be determined as a concentration of resources to perform more tasks in one or two areas - that is, economic, social and environmental. It accordingly allows satisfying the interests of certain groups of stakeholders to a greater extent than others. If a mining company is active in the economic area, then its standing could not be called absolutely sustainable due to the significant ecosystem disruption (social and economic sustainability roll). In turn, the termination of the process of destroying the ecosystem causes social and economic shocks in the territorial development (environmental sustainability roll). Therefore, in this regard, it can be concluded that both the actual mining activities and its termination shall not contribute to the achievement of sustainable development of internal and external environments of the company. This precedes the question of the possibility to ensure sustainable development of a mining company even after its liquidation, as an economic entity.

Sustainability roll is a dynamic characteristic of the mining enterprise development, which is explained by its shift and especially clearly observed in the transition from active mining enterprise economic activity to its termination. This suggests that the roll of the enterprise agile in time. At different points of time, at different stages of development of the enterprise we can see deterioration in the economic, social or environmental internal and external subsystems of the company due to a specific variant of the reallocation of resources.

Taking into consideration all said above, we can formulate the following provision to complement existing theoretical foundations for sustainable development of the mining enterprises. Sustainability in the development of the mining company does not disappear or appear as a permanent feature because the company always has internal economic, social and environmental impact and is always integrated into external upper system. However, the efficiency and effectiveness of sustainable development of the mining enterprise depends on the harmonious interaction of these areas. It is reflected in the roll of sustainability of mining enterprise that is changing in the transitional stages of its operations. Mining company after termination of economic activity also has a roll of its sustainable development at a post-termination stage.

The second and the third contradictions are relevant to life cycle and basic activities of a mining company. In fact mining company according to the core essence of its activities breaks principals of sustainable development not only during the mining process itself but also after being abandoned and closed. Herewith closure of the mining company means as finished mining process so terminated legal entity status. Then the dilemma could be found in mining company sustainable development and overall performance. It is offered to consider that dilemma under the name of Sustainability Roll in Transitive Mining. Further description of it may be encapsulated in the following statements. 
At the moment of terminating the process of digging resources which is the point of actual transition of the mining company from being a mine to uncertain phase of its life cycle a special phenomenon of changing sustainability roll or such roll's occurring could be observed in interaction of economic, social and ecological internal and external systems of the company. The economic nature of the sustainability roll allows defining that the mining company is rolled when resources are concentrated to achieve goals of one or two of three balanced sectors of the company. If it is so, economic interests of certain stakeholders are satisfied more or in a better way. During intensive mining development of the mining company cannot be identified as sustainable absolutely because of dramatic impact on environment. It is therefore social and economic sustainability roll. Destroying environment comes to a stop when mining is recessed. But then social and economic shocks of spatial development occur. It is ecological sustainability roll. Thus as mining company activities so its closure does not contribute to absolute sustainability of interaction of internal and external systems. Consequently a principal question arises whether it is possible to achieve sustainable development of a region or territory where mining company is situated even after its status of legal entity being terminated.

Sustainability roll is a dynamic feature of mining company development that is shown due to its changes occurring at the moment of cutting extraction of minerals off. Hence sustainability may be supposed to roll over time that is different phases of the mining company life cycle can suffer economic, social and environmental slowing down caused by certain model of production factors' distribution.

In addition to current theory of providing development of the mining company according to sustainability principals the following items can be delivered. The mining company sustainability does not appear and vanish but is a permanent for it as the company always has internal economic, social and ecologic environment as well as always is integrated into local (regional) equal systems. But the extent to which sustainable development of the mining company is beneficial economically and efficient socially depends on the level of harmony met by economic, social and ecologic systems in their interacting. Particularly this harmonic interaction can be described by means of sustainability roll that changes during phases of transition. As mentioned above, the mining company also has sustainability roll even after terminating the process of digging minerals and such roll is stuck to post closure phase.

Let's consider in details contradictory challenges arising from mismatch of sustainable development principals and mining company market activities over phases of mining and its stop as well as negative impact of these contradictions on the company itself and local economy.

Primary activities of the mining company for extracting not renewable natural resources come into conflict with the sustainability principal to save nature for future generations. But keeping existing reserves of not renewable natural resources unused that requires a rapid closure of mining company along with complete their exhausting lead to a necessary closure of mining company identically. As a consequence mining company closure directly affects spatial depression while sustainable development supposes economic systems to be developed in a long period to provide high life standards on those territories.

The mining company liquidation requires new investment projects to be found by the owner. For employees it means losses of their jobs. By extension, environment destroyed through mining need to be recovered or otherwise it is the company that has sole responsibility for it and nothing excludes liability for its fraud.

Contradictions pointed out above make risks of shaping or exacerbation of economic, social and ecologic spatial depression with deprivation of source of financing state and local budgets, pushing up unemployment, resettlement and reeducation of miners including members of their families, worsening ecology and having risks of territorial flooding and underground gas methane explosion.

Thus the concept of mining company sustainable development must suggest its life cycle extension through diversifying its activities in a way that ensures absence of sustainability roll particularly during the process of transition from digging minerals to its termination.

The forth conflict item is that socially and ecologically important objects of external environment are not integrated into the model of the mining company particularly into the legal one. But at the same time sustainable development suggests that economic, social and ecologic systems to be closely related. As rule social and ecologic objects are local or the state property so they are not included into the model of the mining company and don't meet distributed company's resources. However the company is relatively responsible for such objects development to achieve its own sustainable development. In this connection a strong factor of interpersonal agreement between owners of the company and social and ecologic objects is to be found that in different cases drives or slows down redistribution of resources for these objects.

Consequently uncertainty of organizational hierarchy and lack of rights and liabilities of the company to run social and ecologic objects located on the nearby territory reserved by law make such objects to be considered by the company only as ones for sponsorship in case of appropriate profit and owner's wish.

For regional economy this contradiction means loss of stable finance source for maintaining social infrastructure and objects of ecologic safety, their destroying and high dependence on decision of company's owner. Thus the concept of the mining company sustainable development must suggest that social and ecologic objects should be integrated into the company model in a certain way.

Conclusions. The above analysis of the existing contradictions between the principles of sustainable development and the principles of the mining enterprise allows to propose to manage the mining enterprise in order to ensure its sustainable development based on the principle of sustainable development based on the value of the object. It should be noted that in the context of the article, the approach of sustainable development based on object value does 
not apply to the widely used in practice costing based on activities, process accounting, accounting center responsible, which demonstrate methods of cost accounting in general.

The main purpose of these methods is to monitor production costs in order to reduce them and redistribute overhead costs. In this case, the object of cost accounting (function, process, cost generation center) differs from the object of costing, which represents products and services.

In contrast to these approaches, the proposed approach to sustainable development aims to analyze the economic activity of the mining company to ensure its sustainable development in order to find and use reserves to enhance the harmony of economic, social and environmental systems by eliminating the above principle of sustainability.

The integration of these provisions in order to adapt to the harmonious development of the mining enterprise can help resolve the conflict between the principles of sustainable development and the rules of a market economy.

\section{References.}

1. Krajnc, D. and Glavic, P. (2005), "How to Compare Companies on Relevant Dimensions of Sustainability", Ecological Economics, vol. 55, pp. 551-563. URL: http://ejournal.narotama.ac.id/files/ANALYSIS.pdf (Accessed 02 February 2021).

2. Marquez, B. Espinoza-Hernandez, I. and Sergio Magdaleno-Palencia, J "Sustainable System Modelling for Urban Development Using Distributed Agencies". URL: http://cdn.intechopen.com/pdfs/29220/InTechSustainable_system_modelling_for_urban_development_using_distributed_agencies.pdf (Accessed 03 February 2021).

3. Angulo. F. et al (2009) "Nonlinear Dynamics and Bifurcation Analysis in Two Models of Sustainable Development”, Revista Internacional Sostenibilidad, Tecnologia y Humanismo, №5, pp. 41-46. URL: http://www.researchgate.net/publication/43067722_Nonlinear_dynamics_and_bifurcation_analysis_in_two_models_of _sustainable_development/file/79e41507d7eaa14395.pdf (Accessed 10 February 2021).

4. Papizh, Yu. (2016), "Features of effective clustering in mining regions of Ukraine", Економічний вісник Донбасу, nо 4(46), pp. 67-69.

5. Phillips, J.A (2010) "Mathematical Model of Sustainable Development Using Ideas of Coupled Environment-Human Systems", The PelicanWeb's Journal of Sustainable Development, vol.6, no5, URL: http://www.pelicanweb.org/solisustv06n05page2jasonphillips.html (Accessed 03 February 2021).

6. Amosha, O.I. Starychenko, L.L. and Cherevats'kyj, D.Yu. (2013) Stan, osnovni problemy i perspektyvy vuhil'noi promyslovosti Ukrainy [State, main problems and prospects of the coal industry of Ukraine], IEP NAN Ukrainy, Donets'k, Ukraine.

7. Bohatykov, V.N. and Khalyullyna, D.N. Kohnytyvnaia model' razvytyia ynnovatsyonnoho predpryiatyia kak slozhnoj dynamycheskoj systemy [Cognitive model of development of an innovative enterprise as a complex dynamic system], URL: http://www.rusnauka.com/4_SND_2013/Tecnic/12_127921.doc.htm (Accessed 03 February 2021).

8. Voronkov, D.K. and Pohorelov, Yu.S. (2009) Rozvytok pidpryiemstva: upravlinnia zminamy ta innovatsii [Enterprise development: change management and innovation], $\operatorname{AdvA}^{\mathrm{TM}}$, Kharkiv, Ukraine.

9. Demeshok, O.O. (2012) "Mekhanizm upravlinnia zabezpechenniam ekonomichnoi bezpeky u promyslovosti”, Ph.D. Thesis, Ekonomika ta upravlinnia natsional'nym hospodarstvom, Donets'k, Ukraine.

10. Amosha, O.I. et al (2015) Kyiv Instytutsional'ne zabezpechennia innovatsijnoho rozvytku vuhil'noi promyslovosti [Institutional support for innovative development of the coal industry], NAN Ukrainy, In-t ekonomiky prom-sti, Kyiv, Ukraine.

11. Malyhyna, S.N. and Abalymova, D.N. (2008) "Razrabotka systemy ymytatsyonnoho modelyrovanyia razvytyia maloho y sredneho promyshlennoho predpryiatyia”, Trudy YSA RAN, T.39, pp. 256-262. URL: http://www.isa.ru/proceedings/images/documents/2008-39/256-262.pdf (Accessed 09 February 2021).

12. Makohon, Yu. Vuhil'na haluz' Ukrainy: problemy ta perspektyvy staloho rozvytku: analitychna zapyska [Coal industry of Ukraine: problems and prospects of sustainable development], URL: http://www.old.niss.gov.ua/Monitor/desember08/5.htm/ (Accessed 07 February 2021).

13. Shvets, V.Ya. Pashkevych, M.S and Papizh, Yu.S. (2013) Analiz protsesiv ta iavysch innovatsijnoho rozvytku v ekonomitsi Ukrainy: vid ekonomiky pidpryiemstva do rehional'noi ekonomiky [Analysis of processes and phenomena of innovative development in the economy of Ukraine: from the economy of the enterprise to the regional economy]. Innovatsijnyj rozvytok ekonomiky: protsesy ta iavyscha [Innovative development of economy: processes and phenomena ], NHU, Dnipro, Ukraine

14. Petrykova, E.M. Systemno-dynamycheskaia model' razvytyia monohoroda [System-dynamic model of monotown development],

URL: http://www.monocityforum.ru/netcat_files/143/180/h_244f008370132958e15b27ea6016ae52 (Accessed 09 February 2021).

15. Protsenko, N.B. (2009) "Organizational and economic mechanism for ensuring long-term economic stability of industrial enterprises", Ph.D. Thesis, Economics and enterprise management (processing industry), Donetsk, Ukraine.

16. Trubchanin, V.V. (2011) "Diversification of production at industrial enterprises", Ph.D. Thesis, Economics and management of enterprises (by type of economic activity), Donetsk, Ukraine.

17. Forrester, D. (1971) Osnovy kibernetiki predprijatija (Industrial'naja dinamika) [Fundamentals of enterprise cybernetics (Industrial dynamics)], Moskva, Rossija. 


\section{Bibliography.}

1. Krajnc D., Glavic P. How to Compare Companies on Relevant Dimensions of Sustainability. Ecological Economics. 2005. №55. P.551-563. URL: http://ejournal.narotama.ac.id/files/ANALYSIS.pdf (дата звернення: 02.02.2021).

2. Marquez B., Espinoza-Hernandez I., Sergio Magdaleno-Palencia J. Sustainable System Modelling for Urban Development Using Distributed Agencies. URL: http://cdn.intechopen.com/pdfs/29220/InTechSustainable_system_modelling_for_urban_development_using_distributed_agencies.pdf (дата звернення: 03.02.2021).

3. Nonlinear Dynamics and Bifurcation Analysis in Two Models of Sustainable Development / F. Angulo et al. Revista Internacional Sostenibilidad, Tecnologia y Humanismo. 2009. №5. P. 41-46. URL: http://www.researchgate.net/publication/43067722_Nonlinear_dynamics_and_bifurcation_analysis_in_two_models_of _sustainable_development/file/79e41507d7eaa14395.pdf (дата звернення: 10.02.2021).

4. Papizh Yu. Features of effective clustering in mining regions of Ukraine. Економічний вісник Донбасу. 2016. № 4(46). P. 67-69.

5. Phillips J.A Mathematical Model of Sustainable Development Using Ideas of Coupled Environment-Human Systems. The PelicanWeb's Journal of Sustainable Development. 2010. Vol.6. №5. URL: http://www.pelicanweb.org/solisustv06n05page2jasonphillips.html (дата звернення: 03.02.2021).

6. Амоша О.І., Стариченко Л.Л., Череватський Д.Ю. Стан, основні проблеми і перспективи вугільної промисловості України: наук. доповідь. Донецьк: ІЕП НАН України, 2013. 44 с.

7. Богатиков В.Н., Халиуллина Д.Н. Когнитивная модель развития инновационного предприятия как сложной динамической системы. URL: http://www.rusnauka.com/4_SND_2013/Tecnic/12_127921.doc.htm (дата звернення: 05.02.2021).

8. Воронков Д.К., Погорелов Ю.С. Розвиток підприємства: управління змінами та інновації: монографія. Харків: АдвА ${ }^{\mathrm{TM}}, 2009.436$ с.

9. Демешок О.О. Механізм управління забезпеченням економічної безпеки у промисловості : автореф. дис. ... д-ра екон. наук : 08.00.03 «Економіка та управління національним господарством» ; Донецьк, 2012.28 с.

10. Інституціональне забезпечення інноваційного розвитку вугільної промисловості: монографія / O.I. Амоша та ін. Київ : НАН України, Ін-т економіки пром-сті, 2015. 196 с.

11. Малыгина С.Н., Абалымова Д.Н. Разработка системы имитационного моделирования развития малого и среднего промышленного предприятия. Труды ИСА PAH. 2008. T.39. C. 256-262. URL: http://www.isa.ru/proceedings/images/documents/2008-39/256-262.pdf (дата звернення: 09.02.2021).

12. Макогон Ю. Вугільна галузь України: проблеми та перспективи сталого розвитку: аналітична записка. URL: Режим доступу: http://www.old.niss.gov.ua/Monitor/desember08/5.htm/ (дата звернення: 07.02.2021).

13. Папіж Ю.С. Аналіз процесів та явищ інноваційного розвитку в економіці України: від економіки підприємства до регіональної економіки. Інноваційний розвиток економіки: процеси та явища: монографія / В.Я. Швець, М.С. Пашкевич, Ю.С. Папіж. Д.: НГУ, 2013. 612 с.

14. Петрикова Е.M. Системно-динамическая модель развития моногорода. URL: http://www.monocityforum.ru/netcat_files/143/180/h_244f008370132958e15b27ea6016аe52 (дата звернення: 09.02.2021).

15. Проценко Н.Б. Організаційно-економічний механізм забезпечення довгострокової економічної стійкості промислових підприємств : автореф. дис. ... канд. екон. наук : 08.00.04 «Економіка та управління підприємствами (переробна промисловість)» ; Донецьк, 2009. 19 с.

16. Трубчанін В.В. Диверсифікація виробництва на промислових підприємствах : автореф. дис. ... д-ра екон. наук : 08.00 .04 «Економіка та управління підприємствами (за видами економічної діяльності)» ; Донецьк, $2011.32 \mathrm{c}$.

17. Форрестер Д. Основы кибернетики предприятия (Индустриальная динамика). М.., 1971. 340 с.

Стаття надійшла до редакиії 25.03.2021 p. 